\title{
Low birthweight infants and total parenteral nutrition immediately after birth. III. Randomised study of energy substrate utilisation, nitrogen balance, and carbon dioxide production
}

\author{
J S Forsyth, N Murdock, A Crighton
}

\begin{abstract}
This study aimed to investigate energy substrate utilisation and nitrogen balance in low birthweight infants receiving total parenteral nutrition during the first days of life, and in particular, to determine the effect of two different glucose intakes on carbon dioxide production. Twenty infants (mean (SE) birthweight 1314 (65) g, mean (SE) gestation $30.9(0.4)$ weeks) were recruited to the study. Immediately after birth they were randomised to a carbohydrate intake of $8 \mathrm{~g} / \mathrm{kg} / \mathrm{day}(5.5 \mathrm{mg} / \mathrm{kg} / \mathrm{minute})$ or $12 \mathrm{~g} / \mathrm{kg} /$ day $(8.3 \mathrm{mg} / \mathrm{kg} / \mathrm{minute})$. After 24 hours they were changed to the alternative regimen which was continued for a further 24 hours. Fat and protein intakes were kept constant throughout the study. Indirect calorimetry was performed during each of the regimens, urine was collected for urinary nitrogen, and substrate utilisation calculated for 12 infants.
\end{abstract}

The carbohydrate utilisation rate was increased during the higher carbohydrate intake. Lipid utilisation rates were significantly different, with net lipid synthesis occurring during high carbohydrate intake. Protein utilisation rates were not influenced by the different carbohydrate intakes. The mean plasma glucose concentration was higher during the high carbohydrate intake but the mean highest and lowest values were not significantly different during the two study periods. A plasma glucose below $2.6 \mathrm{mmol} / \mathrm{h}$ was recorded more frequently during the low glucose intake $(9 / 20 v 5 / 20)$. Capillary PCO2 values measured during high and low glucose intakes were similar $(5.9(0 \cdot 2)$ v $6.2(0 \cdot 3) \mathrm{kPa}$. Carbon dioxide production rates were increased during the higher carbohydrate intake but the differences were not significant. Similarly, there was no significant difference in the respiratory quotients (RQ), oxygen consumption, or energy expenditure during the two study periods.

(Arch Dis Child 1995; 73: F13-F16)

Keywords: total parenteral nutrition, low birthweight infant, nitrogen balance, oxygen consumption.

It is common practice for preterm infants requiring nutritional support to be gradually started on parenteral nutrition over a period of several days. Consequently, the infant is in negative energy and nitrogen balance during the immediate postnatal period. ${ }^{1}$ It is at this time that infants are frequently most sick and in need of optimal nutrition. In an extensive review of parenteral nutrition the lack of evidence to support this practice was highlighted, and in particular, the view that infants were unable to tolerate more than maintenance amounts of amino acids during the immediate neonatal period was questioned. ${ }^{2}$ Although there is now evidence that amino acid solutions and fat emulsions administered separately ${ }^{13}$ and simultaneously ${ }^{4}$ can be tolerated by low birthweight infants during the first days of life, nutritional requirements at this time remain uncertain because of a lack of energy and nitrogen balance studies performed immediately after birth in parenterally fed low birthweight infants.

Data from studies in adults ${ }^{5-7}$ and one study in preterm infants ${ }^{8}$ demonstrate that an intake of glucose above energy requirements results in synthesis of new fat from excess carbohydrate, and that this process significantly increases carbon dioxide production. This may necessitate an increase in minute ventilation and may compromise respiratory function in a susceptible infant. The respiratory quotient (RQ), which is the ratio of carbon dioxide production to oxygen consumption, is greater than 1.0 in those circumstances. ${ }^{6}$ We have reported before that during the first days of life when glucose is the sole energy source and respiratory disease is most prevalent, infants frequently have an $R Q$ in excess of $1 \cdot 0 .{ }^{9}$ Inappropriate glucose intakes may be exacerbating the severity of respiratory disease in these infants.

\section{Methods}

Twenty infants (mean (SE) birthweight 1314 (65) g, mean (SE) gestation $30.9(0.4)$ weeks) were recruited to the study after informed consent had been obtained from parents or guardians. Three infants were receiving artificial ventilation and the remainder were breathing air spontaneously. Immediately after birth they were randomly allocated to a carbohydrate intake of $8 \mathrm{~g} / \mathrm{kg} /$ day $(5.5 \mathrm{mg} / \mathrm{kg} /$ minute) or $12 \mathrm{~g} / \mathrm{kg} /$ day $(8.3 \mathrm{mg} / \mathrm{kg} /$ minute $)$. After 24 hours they were changed to the alternative regimen which was continued for a further 24 hours. Fat and protein intakes were kept constant throughout the study (table 1). 
Table 1 Actual glucose, amino acid, fat and total energy intakes during study regimens

\begin{tabular}{lllll}
\hline & $\begin{array}{l}\text { Glucose } \\
(\mathrm{g} / \mathrm{kg} / \mathrm{d})\end{array}$ & $\begin{array}{l}\text { Protein } \\
(\mathrm{g} / \mathrm{kg} / \mathrm{d})\end{array}$ & $\begin{array}{l}\text { Fat } \\
(\mathrm{g} / \mathrm{kg} / \mathrm{d})\end{array}$ & $\begin{array}{l}\text { Total energy } \\
(\mathrm{kcal} / \mathrm{kg} / \mathrm{d})\end{array}$ \\
\hline High glucose regimen & $12 \cdot 2(0 \cdot 4)$ & $1 \cdot 49(0 \cdot 05)$ & $1 \cdot 81(0 \cdot 04)$ & $73 \cdot 3(4 \cdot 1)$ \\
Low glucose regimen & $8 \cdot 3(0 \cdot 2)$ & $1.54(0 \cdot 05)$ & $1 \cdot 82(0.04)$ & $58 \cdot 0(4 \cdot 0)$ \\
\hline
\end{tabular}

Values: means (SE).

Indirect calorimetry was performed, using methods described before ${ }^{1011}$ for a minimum period of 120 minutes during each study period, and urine was collected for measurement of urinary nitrogen. Substrate utilisation was calculated using the equations described by Consolazio. ${ }^{12}$

Blood gas analysis and blood glucose measurements were performed during the study periods. The infants were nursed in an open intensive care bed or an incubator which provided a thermo-neutral environment. The parenteral fluids were infused through neonatal infusion pumps and volumes were accurately recorded. The study was designed so that the infant would be minimally inconvenienced and routine nursing and clinical procedures could proceed unhindered.

The experimental design was a Latin square crossover in which each infant served as his or her own control. ${ }^{13}$ This design permitted the evaluation of the effect of high $v$ low glucose intake, the effect of time (for example, day $1 v$ day 2), and the effect of order of administration of regimens. The effect of high versus low carbohydrate intake was analysed using the following outcome measures: carbohydrate, fat, and protein utilisation rates; and carbon dioxide production rates. The outcomes were compared using ANOVA and paired $t$ tests.

\section{Results}

The actual nutrient intakes received by the infants during the two study periods are shown in table 1. Carbon dioxide rates were increased during the higher carbohydrate intake but the differences were not significant. Similarly, there was no significant difference in the RQs, oxygen consumption, or energy expenditure during the two study periods (table 2). Adequate paired urine collections for urinary nitrogen measurements were obtained in 12 infants and nutrient utilisation was calculated for these infants (table 3). The carbohydrate utilisation rate was increased during the higher carbohydrate intake. Lipid utilisation rates were significantly different, with net lipid synthesis occurring during high carbohydrate intake. Protein utilisation rates were not influenced by the different carbohydrate intakes. Nutrient utilisation rates were not altered by

Table 2 Carbon dioxide production $\left(\mathrm{VCO}_{2}\right)$, oxygen consumption $\left(\mathrm{VO}_{2}\right)$, respiratory quotient $(R Q)$, and energy expenditure (EE) during study regimens

\begin{tabular}{lllll}
\hline & $\begin{array}{l}\mathrm{VCO}_{2} \\
(\mathrm{~mL} / \mathrm{kg} / \mathrm{min})\end{array}$ & $\begin{array}{l}\mathrm{V \textrm {O } _ { 2 }} \\
(\mathrm{ml} / \mathrm{kg} / \mathrm{min})\end{array}$ & $R Q$ & $\begin{array}{l}E E \\
(\mathrm{kcal} / \mathrm{kg} / \mathrm{d})\end{array}$ \\
\hline High glucose regimen & $6 \cdot 28(0 \cdot 2)$ & $6 \cdot 28(0 \cdot 2)$ & $1.00(0.01)$ & $44 \cdot 8(1.6)$ \\
Low glucose regimen & $5.80(0 \cdot 2)$ & $6.02(0 \cdot 2)$ & $0.97(0.01)$ & $43.0(1.8)$ \\
Difference & $0.48(0.3)$ & $0.27(0.27)$ & $0.03(0.02)$ & $1.80(1.9)$ \\
\hline
\end{tabular}

Values: means (SE). order of administration of regimens or the time of administration (table 4).

The mean plasma glucose concentration was higher during the high carbohydrate intake but the mean highest and lowest values were not significant during the two study periods (table 5). A plasma glucose below $2.6 \mathrm{mmol} / 1$ was recorded more frequently during the low glucose intake (9/20 v 5/20). Capillary PCO2 values measured during high and low glucose intakes were similar $(5.9(0 \cdot 2) v 6 \cdot 2(0 \cdot 3) \mathrm{kPa}$.

\section{Discussion}

This study provides substrate utilisation data for low birthweight infants receiving total parenteral nutrition during the first 48 hours of life. Two parenteral regimens, differing in glucose content but with similar lipid (1.8 $\mathrm{g} / \mathrm{kg} /$ day) and nitrogen content $(1.5 \mathrm{~g} / \mathrm{kg} /$ day), were evaluated. The glucose content of the regimens was based on that frequently administered during the first two days of life ( $8 \mathrm{~g} / \mathrm{kg} /$ day) and that which would be required to ensure a positive energy balance according to recent energy expenditure data $(12 \mathrm{~g} / \mathrm{kg} /$ day $) .^{9}$ The amino acid and lipid composition was based on recent biochemical tolerance studies. ${ }^{134}$ The study shows that a positive energy and nitrogen balance can be achieved immediately after birth with a mix of energy substrates which will not significantly disturb glucose homeostasis or respiratory gas exchange.

During the higher glucose intake, glucose utilisation and retention were increased. Retention during the low glucose regimen was minimal, the intake barely meeting the utilisation demands. These data agree with those of previous studies which have shown that glucose utilisation is directly related to glucose intake. ${ }^{1415}$ Glucose utilisation rate is a measure of the disappearance rate of glucose and does not distinguish between glucose which is being oxidised directly and glucose which is being converted into fat. ${ }^{6}$ Excess glucose is converted to fat when the maximal glucose oxidative rate has been reached. ${ }^{14} 15$ If the non-protein $R Q$ is greater than 1.0 , fat oxidation rate assumes a negative value, indicating that there is net fat synthesis - that is, total fat oxidation minus fat synthesised from

Table 3 Energy balance and substrate utilisation in 12 infants during study regimens

\begin{tabular}{|c|c|c|c|}
\hline & $\begin{array}{l}\text { High glucose } \\
\text { regimen }\end{array}$ & $\begin{array}{l}\text { Low glucose } \\
\text { regimen }\end{array}$ & $\begin{array}{l}\text { Difference } \\
\text { (high-low) }\end{array}$ \\
\hline \multicolumn{4}{|c|}{ Energy (kcal/kg/d): } \\
\hline Intake & $75.9(3.5)$ & $58 \cdot 3(3 \cdot 6)$ & $+17 \cdot 6(2 \cdot 6)^{\star \star}$ \\
\hline Expenditure & $45 \cdot 1$ & 41 & 29) \\
\hline \multicolumn{4}{|l|}{ Glucose $(\mathrm{g} / \mathrm{kg} / \mathrm{d})$ : } \\
\hline Intake & $12 \cdot 6(0 \cdot 6)$ & $8 \cdot 4(0 \cdot 3)$ & $4 \cdot 17(0 \cdot 39)$ \\
\hline Utilise & 10 & & $2 \cdot 1$ \\
\hline Retention & $2 \cdot 18(1 \cdot 1)$ & $0.03(0 \cdot 6)$ & $2 \cdot 16(1 \cdot 1)$ \\
\hline \multicolumn{4}{|l|}{ Fat $(g / \mathrm{kg} / \mathrm{d})$ : } \\
\hline Intake & $1.85(0.05)$ & $1.81(0.05)$ & $0.04(0.06)$ \\
\hline Utilisation & $-0.16(0$ & & $-0.61(0.25)^{\star}$ \\
\hline Retention & $2 \cdot 0(0 \cdot 2$ & $1.36(0.20)$ & $0.64(0.28)^{\star}$ \\
\hline \multicolumn{4}{|l|}{ Protein $(g / k g / d)$ : } \\
\hline Intake & $1.56(0.07)$ & $1.55(0.06)$ & $0.01(0 \cdot 15)$ \\
\hline Utilisation & $0.70(0.08)$ & $0.74(0.12)$ & $-0.02(0.15)$ \\
\hline Retention & $0.85(0.12)$ & $0.81(0.15)$ & $+0.02(0.18)$ \\
\hline
\end{tabular}

Values: means (SE). ${ }^{\star} \mathrm{P}<0.05,{ }^{\star} \star \mathrm{P}<0.01$. 
Table 4 Effect of time and order of administration of study regimens on nutrient utilisation rates

\begin{tabular}{|c|c|c|c|c|c|c|}
\hline \multirow[b]{2}{*}{$\begin{array}{l}\text { Utilisation } \\
\text { rate }\end{array}$} & \multicolumn{3}{|l|}{ Day 1} & \multicolumn{3}{|l|}{ Day 2} \\
\hline & $\begin{array}{l}\text { High glucose } \\
(n=6)\end{array}$ & $\begin{array}{l}\text { Low glucose } \\
(n=6)\end{array}$ & $\begin{array}{l}\text { Difference } \\
\text { (high-low) }\end{array}$ & $\begin{array}{l}\text { High glucose } \\
(n=6)\end{array}$ & $\begin{array}{l}\text { Low glucose } \\
(n=6)\end{array}$ & $\begin{array}{l}\text { Difference } \\
\text { (high-low) }\end{array}$ \\
\hline $\begin{array}{l}\text { Glucose } \\
\text { Fat } \\
\text { Protein }\end{array}$ & $\begin{array}{c}10.4(1.1) \\
-0.07(0.4) \\
0.74(0.16)\end{array}$ & $\begin{array}{l}8.4(0.3) \\
0.48(2 \cdot 26) \\
0.74(0.16)\end{array}$ & $\begin{array}{r}2.0(1.1) \\
-0.6(0.6) \\
-0.0(0.2)\end{array}$ & $\begin{array}{r}10.9(1.0) \\
-0.24(0.29) \\
0.84(0.21)\end{array}$ & $\begin{array}{l}8.4(1.0) \\
0.42(0.36) \\
0.75(0.19)\end{array}$ & $\begin{array}{r}2.6(0.4) \\
-0.7(0.3) \\
0.1(2.8)\end{array}$ \\
\hline
\end{tabular}

Values:means (SE) g/kg/day.

glucose. The amount of glucose carbon converted to fat during this process of lipogenesis can be measured by determining the difference between glucose utilisation measured by indirect calorimetry and glucose oxidation estimated using [U-13 $\mathrm{C}]$ glucose infusion studies. ${ }^{1415}$ The amount can also be calculated from non-protein oxygen consumption and carbon dioxide production according to the calculations of Lillioja and colleagues. ${ }^{16}$ In our study there was a very small negative fat oxidation rate during the high glucose intake, indicating that less than $0.5 \mathrm{~g} / \mathrm{kg} /$ day of glucose was being converted to fat. This suggests that for low birthweight infants, during the first days of life, the maximal glucose oxidative rate is in the region of $10 \mathrm{~g} / \mathrm{kg} /$ day (7 $\mathrm{mg} / \mathrm{kg} / \mathrm{minute}$ ). These data are consistent with those reported by Sauer and colleagues ${ }^{14}$ and also those of Bresson and colleagues ${ }^{15}$ after adjustments for differences in energy expenditures have been made. When the fat intake was added to the net fat synthesis rate the total fat storage achieved during the high glucose regimen was similar to in utero fat accretion rates for that gestation. ${ }^{17}$

During lipogenesis there is a substantial increase in carbon dioxide production. ${ }^{5}$ Healthy adults compensate for the increased carbon dioxide production by increasing minute ventilation, ${ }^{6}$ but in patients with respiratory disease, hypercapnia necessitating increased ventilation has been described. ${ }^{7}$ In one previous study involving preterm infants aged 5-21 days, the infants receiving higher glucose loads (15 g/kg/day) had significantly increased rates of carbon dioxide production, RQs, transcutaneous $\mathrm{PCO} 2$ and alveolar minute ventilation compared with infants receiving lower glucose intakes $(10 \mathrm{~g} / \mathrm{kg} /$ day $){ }^{8}$ In our study in which the glucose intakes were lower, carbon dioxide production was increased during the high carbohydrate intake but the difference was not significant. The mean RQ for both regimens was 1.0 or less. Measurements of respiratory function were not performed in our study but $\mathrm{PCO} 2$ values measured at the beginning and the end of each trial regimen did not significantly differ,

Table 5 Plasma glucose concentrations during study regimens

\begin{tabular}{|c|c|c|c|}
\hline $\begin{array}{l}\text { Glucose } \\
\text { (mmolll) }\end{array}$ & $\begin{array}{l}\text { High glucose } \\
\text { regimen }\end{array}$ & $\begin{array}{l}\text { Low glucose } \\
\text { regimen }\end{array}$ & $\begin{array}{l}\text { Difference } \\
\text { (high-low) }\end{array}$ \\
\hline $\begin{array}{l}\text { Mean } \\
\text { Highest } \\
\text { Lowest }\end{array}$ & $\begin{array}{l}4.8(0.3) \\
6 \cdot 25(0 \cdot 4) \\
3 \cdot 0(0 \cdot 2)\end{array}$ & $\begin{array}{l}4.3(0.4) \\
5.7(0.5) \\
3.1(0.4)\end{array}$ & $\begin{array}{c}0.42(0.19)^{\star} \\
0.47(0.35) \\
-0.15(0.41)\end{array}$ \\
\hline
\end{tabular}

Values: means (SE). ${ }^{\star} \mathrm{P}<0 \cdot 05$. suggesting that the mild increase in carbon dioxide production during the higher glucose intake did not compromise respiratory function.

The plasma glucose values were higher during the high carbohydrate regimen but remained within normal limits, and fewer infants on this regimen experienced a plasma glucose of less than $2.6 \mathrm{mmol} / \mathrm{l}$.

Protein utilisation was not significantly influenced by varying glucose intake and a moderate nitrogen retention was achieved during both regimens. An early study showed that low birthweight infants who were starved during the first days of life catabolised body protein stores at a rate of $1 \mathrm{~g} / \mathrm{kg} /$ day. ${ }^{18}$ Although this can be partially reversed by the provision of glucose, infants receiving parenteral feeding regimens that are devoid of amino acids will remain in negative nitrogen balance. ${ }^{2}$ If amino acids are provided positive nitrogen retention can be achieved even in the presence of energy intakes as low as 35 $\mathrm{kcal} / \mathrm{kg} /$ day. ${ }^{19}$ Further increases in nitrogen retention can be obtained by enhancing energy intake, but once this has exceeded 70 $\mathrm{kcal} / \mathrm{kg} /$ day, the actual intake of nitrogen becomes the major determinant of nitrogen retention. ${ }^{20}$ As protein retention rates in our study were lower than intrauterine retention rates of similar gestational age, ${ }^{17}$ and the energy intake in the high glucose regimen was $75 \mathrm{kcal} / \mathrm{kg} /$ day, an increase in amino acid intake would be required to enhance further nitrogen retention at this time.

There are currently no formal guidelines on energy and nutrient intakes for sick preterm infants. The ESPGAN guidelines for the nutritional requirements of preterm infants make no specific recommendations for the nutritional management of infants fed by the parenteral route. ${ }^{21}$ From our study of infants who were considered to be sufficiently unwell not to tolerate enteral feeds, the administration immediately after birth of a parenteral regimen consisting of glucose $10-12 \mathrm{~g} / \mathrm{kg} /$ day, amino acids $1 \cdot 5-2 \cdot 0 \mathrm{~g} / \mathrm{kg} /$ day, and lipid $1 \cdot 8-2 \cdot 0$ $\mathrm{g} / \mathrm{kg} /$ day will meet energy and protein requirements for maintenance and continuing growth.

We gratefully acknowledge support for this study from the Chest, Heart and Stroke Association (Scotland), the Scottish Home and Health Department, and Cow \& Gate Nutricia.

1 Saini JR, MacMahon P, Morgan JB, Kovar IZ. Early parenteral feeding of amino acids. Arch Dis Child 1989; 64: 1362-6.

2 Heird WC. Parenteral feeding. In: Sinclair JC, Bracken MB, eds. Effective care of the newborn infant. Oxford: Oxford University Press, 1992: 141-60.

3 Gilbertson N, Kovar IZ, Cox DJ, Crowe L, Palmer NT. Introduction of intravenous lipid administration on the first day of life in the very low birth weight neonate. $\mathcal{f}$ Pediatr 1991; 119: 615-23.

4 Murdock N, Crighton A, Nelson LM, Forsyth JS. Low birthweight infants and total parenteral nutrition immedibirthweight infants and total parenteral nutrition immediately after birth. II. Randomised study of biochemical
tolerance of intravenous glucose, amino acids, and lipid. tolerance of intravenous glucose,
Arch Dis Child 1995; 73: F8-F12.

5 Askanazi J, Rosenbaum SH, Hyman AI, Silverberg PA, Milic-Emili J, Kinney JM. Respiratory changes induced by the large glucose loads of total parenteral nutrition. ҰAMA 1980; 243: 1444-7.

6 Acheson KJ, Schutz Y, Bessard T, Ravussin E, Jequier E. Nutritional influences on lipogenesis and thermogenesis after a carbohydrate meal. Am $\mathcal{\Im}$ Physiol (Endocrinol Metab 9) 1984; 246: E62-70.

7 Covelli HD, Black JW, Olsen MS, Jerome F, Beekman MD. Respiratory failure precipitated by high carbohydrate
loads. Ann Intern Med 1981; 95: 579-81. 
8 Piedboeuf B, Chessex P, Hazan J, Pineault M, Lavoie J-C. Total parenteral nutrition in the newborn infant: Energy substrates and respiratory gas exchange. $\mathcal{F}$ Pediatr 1991; 118: $97-102$

9 Forsyth JS, Crighton A. Low birthweight infants and total parenteral nutrition immediately after birth. I. Energy expenditure and respiratory quotient of ventilated and non-ventilated infants. Arch Dis Child 1995; 73: F4-F7.

10 Forsyth JS, Crighton A. An indirect calorimetry system for ventilator dependent very low birthweight infants. Arch Dis Child 1992; 67: 315-9.

11 Shortland GJ, Fleming PJ, Walter JH. Validation of a portable indirect calorimetry system for measurement of portable indirect calorimetry system for measurement of 1992; 67: 1207-11.

12 Consolazio CJ, Johnson RE, Pecora LJ. Physiological measurements of metabolic functions in man. New York: McGraw-Hill, 1963.

13 Hills M, Armitage PL. The two-period cross-over clinical trial. Br f Clin Pharmacol 1979; 8: 7-20.

14 Sauer PJ, Van Aerde, Pencharz PB, Smith JM, Swyer PR. Glucose oxidation rates in newborn infants measured with indirect calorimetry and $\left[\mathrm{U}^{13} \mathrm{C}\right]$ glucose. Clin $\mathrm{Sci} 1986$; 70: 587-93.
15 Bresson JL, Putet NG, Ricour C, Sachs C, Rey J. Energy substrate utilisation in infants receiving total parenteral nutrition with different glucose to fat ratios. Pediatr Res 1989; 25: 645-8.

16 Lillioja S, Bogardus C, Mott DM, Kennedy AL, Knowler WC, Howard BV. Relationship between insulin mediated glucose disposal and lipid metabolism in man. $\mathcal{f}$ Clin Invest 1985; 75: 1106-15.

17 Widdowson EM, Dickerson JWT. Chemical composition of the body. In: Comar CL, Bronner F, eds. Mineral Metabolism. New York: Academic Press, 1964: 1-247.

18 Auld PAM, Bhangananda $P, M e h t a S$. The influence of an early caloric intake with I-V glucose on catabolism, of premature infants. Pediatrics 1966; 37: 592-6.

19 Anderson TL, Muttart CR, Bieber MA, Nicholson JF, Heird WC. A controlled trial of glucose versus glucose Heird WC. A controlled trial of glucose versus glucose
and amino acids in premature infants. $\mathcal{F}$ Pediatr 1979; 94:

20 Zlotkin SH, Bryan MH, Anderson GH. Intravenous nitrogen and energy intakes required to duplicate in utero nitrogen accretion in prematurely born human infants. f Pediatr 1981; 99: 115-20.

21 Wharton BW. Nutrition and feeding of preterm infants. London: Blackwell Scientific Publications, 1987. 